Distribution, Abundance and Molecular Analysis of Genus Barbadocladius

Cranston \& Krosch (Diptera,

Chironomidae) in Tropical, High Altitude Andean Streams and Rivers

N Prat, C Ribera, M Rieradevall, C Villamarín \& R Acosta

Neotropical Entomology

ISSN 1519-566X

Neotrop Entomol

DOI 10.1007/s13744-013-0161-1

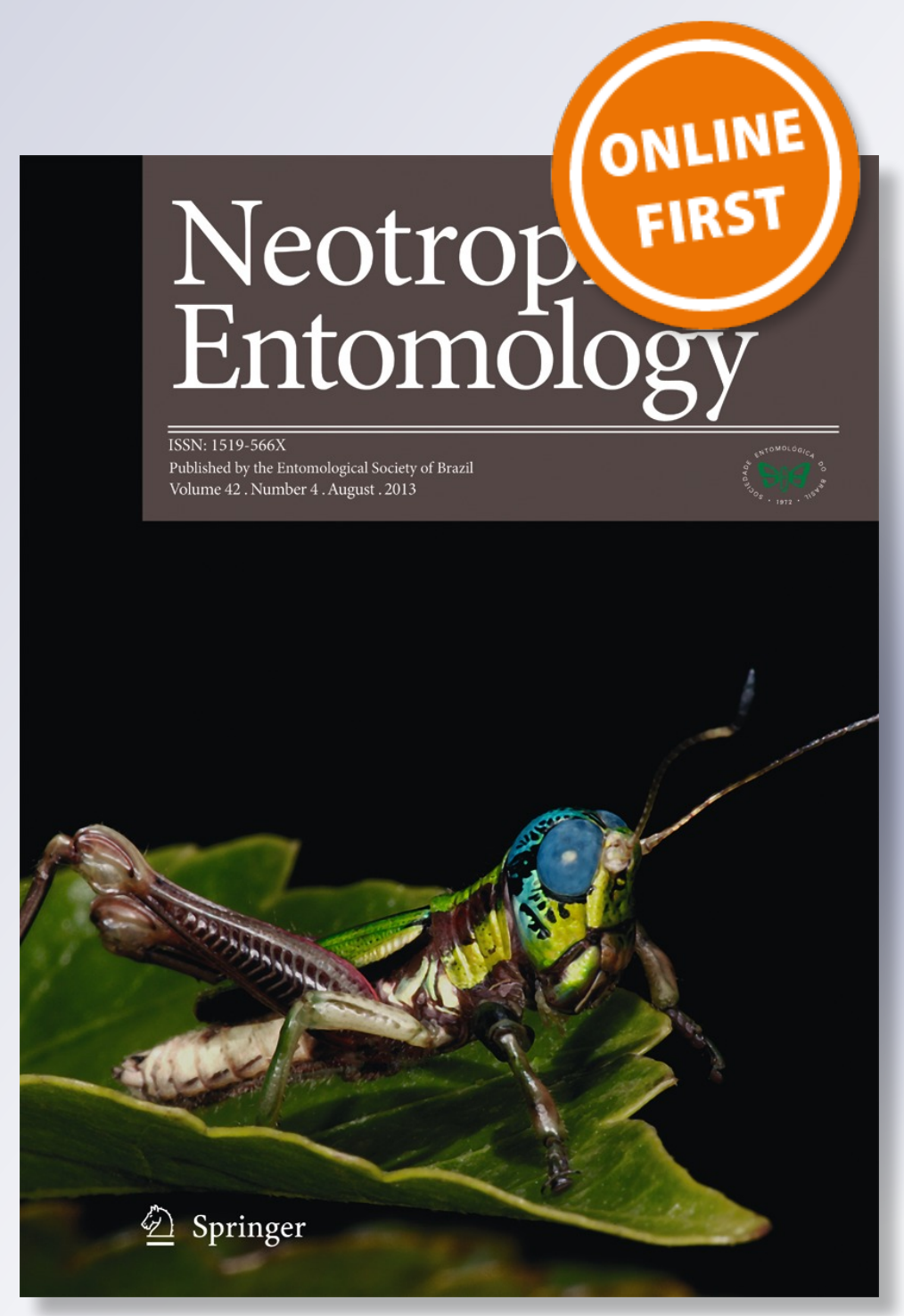

望 Springer 
Your article is protected by copyright and all rights are held exclusively by Sociedade Entomológica do Brasil. This e-offprint is for personal use only and shall not be selfarchived in electronic repositories. If you wish to self-archive your article, please use the accepted manuscript version for posting on your own website. You may further deposit the accepted manuscript version in any repository, provided it is only made publicly available 12 months after official publication or later and provided acknowledgement is given to the original source of publication and a link is inserted to the published article on Springer's website. The link must be accompanied by the following text: "The final publication is available at link.springer.com". 


\title{
Distribution, Abundance and Molecular Analysis of Genus Barbadocladius Cranston \& Krosch (Diptera, Chironomidae) in Tropical, High Altitude Andean Streams and Rivers
}

\author{
N Prat ${ }^{1}$, C Ribera ${ }^{2,3}$, M Rieradevall ${ }^{1,3}$, C Villamarín ${ }^{1}$, R Acosta $^{1}$ \\ ${ }^{1}$ Grupo de investigación Freshwater Ecology and Management (F.E.M.), Depto d'Ecologia, Univ de Barcelona, Barcelona, Spain \\ ${ }^{2}$ Depto de Biologia Animal, Univ de Barcelona, Barcelona, Spain \\ ${ }^{3}$ Institut de Recerca de Biodiversitat (IRBio), Univ de Barcelona, Barcelona, Spain
}

\section{Keywords}

Aquatic insects, biogeography, midges, Orthocladiinae, taxonomy

\section{Correspondence}

N Prat, Grupo de investigación Freshwater Ecology and Management (F.E.M.), Depto d'Ecologia, Univ de Barcelona, 08028 Barcelona, Spain; nprat@ub.edu

Edited by Roberto A Zucchi - ESALQ/USP

Received 22 May 2013 and accepted 3 August 2013

(C) Sociedade Entomológica do Brasil 2013

\begin{abstract}
The distribution of the genus Barbadocladius Cranston \& Krosch (Diptera: Chironomidae), previously reported from Chile to Bolivia, has extended northwards. Larvae, pupae and pupal exuviae of this genus have been found in the high mountain tropical streams of Peru to $9^{\circ} 22^{\prime} 56^{\prime \prime}$, but are restricted to very high altitude streams (altitudes over 3,278 $\mathrm{m}$ asl) compared to the lower altitude streams (below 1,100 $\mathrm{m}$ asl) in which the genus is reported in Chile and Argentina. Based on morphological studies, both described species in the genus, Barbadocladius andinus Cranston \& Krosch and Barbadocladius limay Cranston \& Krosch, have been found in Peru as pupae or pupal exuviae. Morphological analysis of the larvae and pupae revealed no differences between the two described species from Patagonia and Peru, which are of similar size and with a similar armament of hooklets and spines in pupal tergites and sternites. However, molecular analysis of larvae and pupae revealed that in Peru, there are at least two different evolutionary lines, one distributed widely and another restricted to one site. Phylogenetic analysis (using cox 1 mitochondrial sequences) of all available sequences of Barbadocladius shows that the Chilean and Argentinean material differs from that of Peru. Therefore, a total of four molecular segregates are identified, although morphologically, neither larvae nor the pupae may be differentiated.
\end{abstract}

\section{Introduction}

The Chironomidae (Diptera) genus Barbadocladius was established by Cranston \& Krosch (2011), and its name refers to the long and dense beard of setae located at the lateral to posterior mentum of the larval head. This distinctive larva was first described in 1983 by S.H. Roback \& P. Coffmann as "Genus 9", possessing an unknown combination of characters for a chironomid larva (Roback \& Coffmann 1983). In the same paper, these authors described a very unusual pupa as "Genus 4". These two unnamed genera have since been associated with each other, named as genus Barbadocladius, and described in all morphological stages by Cranston \& Krosch (loc.cit.). Two species were described by these authors, Barbadocladius andinus Cranston \& Krosch and Barbadocladius limay Cranston \& Krosch, including molecular data. In this paper, two specimens of larvae were analysed using partial sequences of mtDNA COI and two nuclear protein-coding genes (CAD1 and CAD3). In another paper (Krosh et al 2011), the molecular phylogenetic analysis of two larval specimens (not associated with either species described morphologically) placed the genus as a sister group to a large and diverse clade estimated to comprise taxa largely of "Gondwanan" distribution.

The original material of Roback \& Coffmann (1983) for Genus 4 and Genus 9 specimens was collected in Bolivia ca. 55 km East of La Paz in 1977 at 4,200 m asl, while Cranston \& Krosch (2011) collected additional material of Barbadocladius 
in Chile and Argentina in 1997 and 2006, further south from the original finding. Keys to distinguish the adults and the pupae were provided in the paper describing the genera and the two species mentioned above; the larvae are indistinguishable. According to the authors' description, Barbadocladius is a trans-Andean genus located between $39^{\circ}$ and $41^{\circ} \mathrm{S}$, and living from the lowlands to altitudes up to $1,100 \mathrm{~m}$ asl. Nevertheless, Barbadocladius distribution has not been studied in the tropical high Andes.

In our previous studies of Chironomidae biodiversity in streams in the highland Andes from Peru to Colombia, we have occasionally found larvae and pupae of Barbadocladius, but never in great abundance (Acosta \& Prat 2010, Villamarín 2012). Recently, in a project specifically dealing with Chironomidae distribution and molecular variability in the Andes over 2,000 $\mathrm{m}$ asl from the central part of Colombia to southern Peru (project BIQURA, =B/odiversidad de QUironómidos de Ríos Altoandinos, http://www.ub.edu/ riosandes/index.php/biqura.html), we collected more specimens of genus Barbadocladius. In this paper, we report new findings of larvae, pupae and pupal exuviae of this genus and its phylogenetic relationships using cox1 mitochondrial sequences.

\section{Study area}

The study area consisted of 193 sites from central Colombia to southern Peru, between the latitudes $5^{\circ}$ North and $16^{\circ}$ South (Fig 1 and Table 1). We have included data from our present and past research projects, including the Ph.D. thesis of R. Acosta (Acosta \& Prat 2010) and C. Villamarín (unpublished data). Of the 17 basins listed in Table 1, a selection of 8 were sampled for molecular analysis as part of the BIQURA project: (1) 4 tributaries of the Amazon river that eventually drains into Atlantic Ocean (eastern range) and (2) 4 rivers delivering their water to the Pacific Ocean (western range). In each basin of the BIQURA project, a number of sampling sites were visited for collection, some at the highest altitudes $(>3,500 \mathrm{~m}$ asl) where rivers and basins lack riparian vegetation (the so-called Páramo or Puna areas), and others between 2,000 and 3,500 $\mathrm{m}$ asl, where usually both the basin and the riparian zone are covered by trees. All sites were located in areas not or scarcely disturbed by man (close to reference conditions) and without any important source of water pollution (including the absence of mining).

Of all the sites sampled, Barbadocladius was found in 13 (in 5 of the 17 investigated basins; Fig 1) a total of 14 times (in one site, it was found on two different dates). The exact locations and general environmental characteristics of the sampling sites, together with the material found at each site, are listed in Table 2.

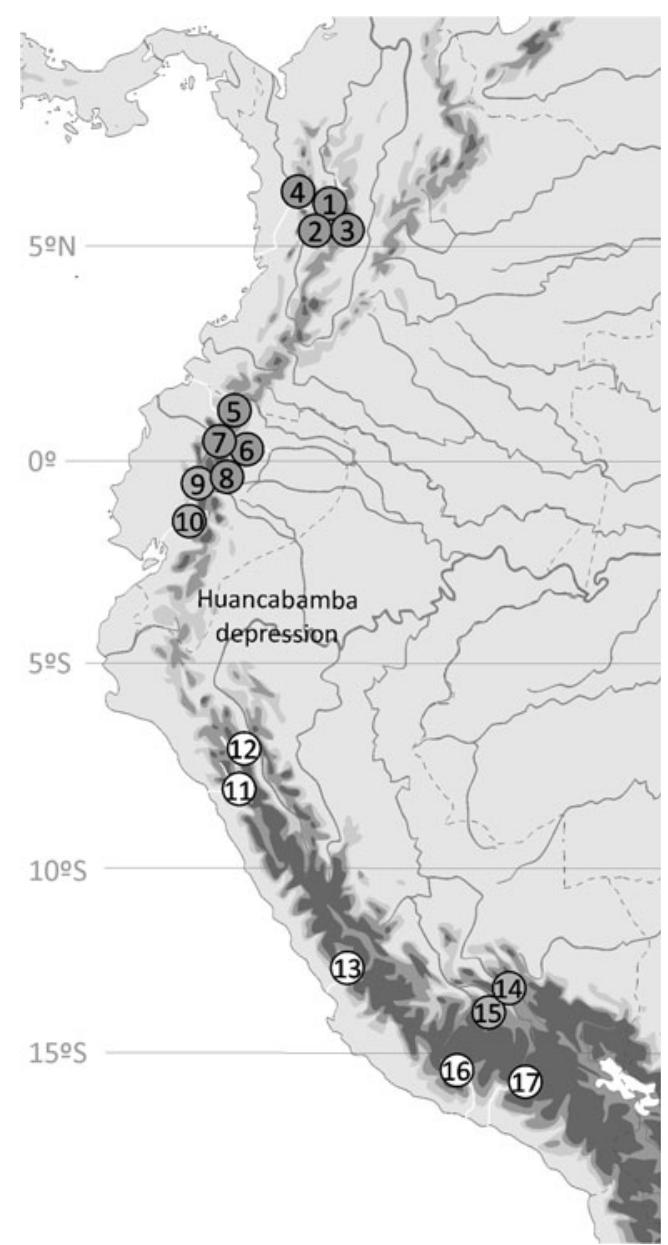

Fig 1 Map showing the localization of the different river basins studied in the tropical high Andean area. For details, see Table 1. The individuals of genus Barbadocladius were found only in basins 11, 12, 13, 16 and 17.

\section{Material and Methods}

\section{Sampling and processing of samples for morphological} and molecular analysis

The collection of macroinvertebrates for BIQURA samples was conducted in 2011 (exact dates in Table 2). The sampling strategy in the BIQURA project was designed to maximize Chironomidae diversity. Surber samples and Drift samples were taken simultaneously. Surber samples were taken in different substrates following the protocol described by Núñez \& Prat (2010) and Villamarín et al (2013). At each site, samples were examined in the field, and at least 100 larval midges were picked out from each sample and preserved in $96 \%$ ethanol for DNA analysis. At the same time, at least two drift samples were collected at each site while the sampling and sorting of benthos from the Surber samples took place (2-3 $h$ of exposure). The main purpose of collecting drift samples was to collect pupae and pupal exuviae. The sorting and classification of drift samples took place at the laboratory. All specimens used for molecular analysis were preserved in $96 \%$ ethanol. 
Table 1 Basins sampled for the study of the Chironomidae biodiversity of the tropical, high altitude, Andean streams and rivers.

\begin{tabular}{|c|c|c|c|c|c|c|}
\hline Code in Fig 1 & Country & Basin & Side & $\begin{array}{l}\text { No. of sites } 2,000- \\
3,000 \mathrm{~m} \text { asl }\end{array}$ & $\begin{array}{l}\text { No. of sites } \\
>3,000 \mathrm{~m} \text { asl }\end{array}$ & Research project \\
\hline 1 & Colombia & Chinchiná-Cauca-Magdalena & Atlantic-Caribean & 4 & 2 & BIQURA \\
\hline 2 & Colombia & Campoalegre-Cauca-Magdalena & Atlantic-Caribean & 2 & 0 & BIQURA \\
\hline 3 & Colombia & Gualí-Magdalena & Atlantic-Caribean & 0 & 2 & BIQURA \\
\hline 4 & Colombia & San Juan & Pacific & 2 & o & BIQURA \\
\hline 5 & Ecuador & Mira & Pacific & 6 & 10 & CERA \\
\hline 6 & Ecuador & Aguarico-Napo & Atlantic-Amazon & 8 & 6 & CERA \\
\hline 7 & Ecuador & Guayllabamba-Esmeraldas & Pacific & 2 & 5 & BIQURA \\
\hline 8 & Ecuador & Papallacta, Tambo-Napo & Atlantic-Amazon & 3 & 3 & BIQURA \\
\hline 9 & Ecuador & Pastaza-Marañón & Atlantic-Amazon & 8 & 8 & CERA \\
\hline 10 & Ecuador & Guayas & Pacific & 12 & 3 & CERA \\
\hline 11 & Peru & Santa & Pacific & 1 & 15 & CERA, BIQURA \\
\hline 12 & Peru & Mosna-Marañón & Atlantic-Amazon & 4 & 12 & CERA, BIQURA \\
\hline 13 & Peru & Cañete & Pacific & 5 & 30 & Acosta Ph.D. thesis \\
\hline 14 & Peru & Urubamba & Atlantic-Amazon & 0 & 15 & CERA \\
\hline 15 & Peru & Ampay-Apurimac & Atlantic-Amazon & 3 & 4 & BIQURA \\
\hline 16 & Peru & Cotahuasi-Ocoña & Pacific & 0 & 7 & BIQURA \\
\hline 17 & Peru & Colca-Camaná & Pacific & 2 & 13 & CERA \\
\hline
\end{tabular}

Information reported here refers to country, river basin name, topographical orientation of the basin (side) and the number of sampling sites grouped in two altitudinal ranges (between 2,000 and 3,000 $\mathrm{m}$ a.s.l. and those above 3,000 $\mathrm{m}$ a.s.l.).

BIQURA Blodiversidad de QUironómidos en Ríos A Itoandinos (Sampling in 2011); CERA Calidad Ecológica de Ríos Altoandinos (Sampling in 2007, from Villamarín Ph. D. thesis). Samples from Acosta Ph.D. thesis were taken in 2005.

Table 2 Sites where Barbadocladius specimens have been found.

\begin{tabular}{|c|c|c|c|c|c|c|c|c|c|c|c|}
\hline $\begin{array}{l}\text { Sites } \\
\text { Code }\end{array}$ & Date & Basin & Side & River name & $\begin{array}{l}\text { Altitude } \\
\text { ( } \mathrm{m} \text { asl) }\end{array}$ & Longitude & Latitude & $\begin{array}{l}\text { Temperature } \\
\left({ }^{\circ} \mathrm{C}\right)\end{array}$ & $\begin{array}{l}\text { Conductivity } \\
\mu \mathrm{S} / \mathrm{cm}\end{array}$ & $\begin{array}{l}\text { Flow } \\
(1 / s)\end{array}$ & $\begin{array}{l}\text { Individuals } \\
\text { examined }\end{array}$ \\
\hline \multicolumn{12}{|l|}{ BIQURA } \\
\hline соTо1 & 12/July/2011 & Ocoña & Pacific & Huancarama & 3,278 & $72^{\circ} 54^{\prime} 51^{\prime \prime}$ & $15^{\circ} 7^{\prime} 45^{\prime \prime}$ & 7.9 & 35.2 & 16.1 & $6 \mathrm{~L}$ \\
\hline СOTO2 & 13/July/2011 & Ocoña & Pacific & Sumana & 3,470 & $72^{\circ} 40^{\prime} 50^{\prime \prime}$ & $15^{\circ} 3^{\prime} 42^{\prime \prime}$ & 6.6 & 82.4 & 1184.2 & $13 \mathrm{~L}+3 \mathrm{P}$ \\
\hline СОTоз & 13/July/2011 & Ocoña & Pacific & Manantial S/N & 3,854 & $72^{\circ} 42^{\prime} 4^{\prime \prime}$ & $15^{\circ} 1^{\prime} 14^{\prime \prime}$ & 11.8 & 29.1 & 40.8 & $4 \mathrm{~L}$ \\
\hline COTO4 & 13/July/2011 & Ocoña & Pacific & $\mathrm{S} / \mathrm{N}$ & 3,640 & $72^{\circ} 42^{\prime} 43^{\prime \prime}$ & $14^{\circ} 59^{\prime} 10^{\prime \prime}$ & 9.8 & 15.0 & & $6 \mathrm{~L}$ \\
\hline COTO5 & 14/July/2011 & Ocoña & Pacific & Chinche & 4,486 & $72^{\circ} 38^{\prime} 32^{\prime \prime}$ & $14^{\circ} 54^{\prime} 15^{\prime \prime}$ & 7.4 & 13.7 & 632.0 & $2 \mathrm{~L}$ \\
\hline СOTO7 & 14/July/2011 & Ocoña & Pacific & Ajoruro & 4,670 & $72^{\circ} 38^{\prime} 20^{\prime \prime}$ & $14^{\circ} 55^{\prime} 28^{\prime \prime}$ & 3.6 & 130.7 & 42.5 & $1 \mathrm{~L}$ \\
\hline SA15Der & 03/July/2011 & Santa & Pacific & Yanayacu & 3,582 & $77^{\circ} 24^{\prime} 54^{\prime \prime}$ & $9^{\circ} 46^{\prime} 31^{\prime \prime}$ & 8.0 & 33.6 & 748.0 & 10Pex \\
\hline SA05Der & 01/July/2011 & Santa & Pacific & Ishinca & 3,364 & $77^{\circ} 31^{\prime} 19^{\prime \prime}$ & $9^{\circ} 22^{\prime} 56^{\prime \prime}$ & 10.0 & 26.0 & 799.7 & 5 Pex \\
\hline \multicolumn{12}{|l|}{ Other } \\
\hline CA01 & $\begin{array}{l}\text { 09/September/ } \\
2004\end{array}$ & Cañete & Pacific & Cañete & 4,396 & $76^{\circ} \mathrm{o}^{\prime} 54^{\prime \prime}$ & $12^{\circ} 9^{\prime} 6^{\prime \prime}$ & 7.0 & 70.0 & 257.5 & $3 \mathrm{~L}$ \\
\hline CAO6 & 01/March/2005 & Cañete & Pacific & Estanza & 3,913 & $75^{\circ} 51^{\prime} 49^{\prime \prime}$ & $12^{\circ} 5^{\prime} 29^{\prime \prime}$ & 2.0 & 420.0 & 455.0 & $10 \mathrm{~L}$ \\
\hline CAO6 & 24/May/2005 & Cañete & Pacific & Estanza & 3,913 & $75^{\circ} 51^{\prime} 49^{\prime \prime}$ & $12^{\circ} 5^{\prime} 29^{\prime \prime}$ & 2.0 & 420.0 & 455.0 & 1Pex \\
\hline $\mathrm{CO} 10$ & 06/October/2008 & Colca & Pacific & Escalera & 3,778 & $71^{\circ} 35^{\prime} 21^{\prime \prime}$ & $15^{\circ} 38^{\prime} 33^{\prime \prime}$ & 2.0 & 19.6 & 63.0 & 1Pex \\
\hline $\mathrm{MO}_{3}$ & 21/October/2007 & Mosna & Atlantic & Mosna & 3,282 & $77^{\circ} 11^{\prime} 44^{\prime \prime \prime}$ & $9^{\circ} 37^{\prime} 42^{\prime \prime}$ & 11.7 & 91.6 & & $1 \mathrm{~L}+2 \mathrm{Pex}$ \\
\hline MO10 & 22/October/2007 & Mosna & Atlantic & Garguanga & 3,485 & $77^{\circ} 25^{\prime} 33^{\prime \prime}$ & $9^{\circ} 10^{\prime} 53^{\prime \prime}$ & 11.7 & 35.3 & & 1Pex \\
\hline
\end{tabular}

BIQURA sites are the ones used for molecular analysis (COT Cotahuasi basin; SA Santa river basin). Only larvae ( $L$ ) and pupae (P) were prepared for molecular analysis (Pupal exuviae, Pex, were examined only morphologically). For other sites than those of BIQURA project, data are from Acosta Ph. D. thesis (CA Cañete river) and Villamarín Ph. D. thesis. (CO Colca river basin; MO Mosna river basin). For the location of the basins, see Fig 1 and Table 1. $S / N$ means no known name of the river is available (from the Spanish 'Sin Nombre'). 
At the laboratory, the larvae of Chironomidae were grouped into different morphotypes under a stereo microscope, and identified using the key of Prat et al (2012). If different genera have similar morphotypes, we grouped the animals under the name "morphotype \#1". For each morphotype, up to five to ten individuals were prepared in the following manner: The head was dissected from the thorax, digested in hot $10 \% \mathrm{KOH}$, washed, dehydrated and mounted in Euparal ${ }^{\circledR}$ on a slide following the usual techniques for optical microscopy described by Epler (2001). The body was then used for destructive DNA extraction. A total of 32 Barbadocladius larvae were found at six different BIQURA sites (Table 2). Only three pupae were found in all the BIQURA sites, and before DNA extraction, they were classified as B. andinus according to Cranston \& Krosch (2011). One pupa was used for DNA extraction, and two were prepared for examination under the microscope using the techniques of Cranston \& Krosch (2011). None of the three pupae were mature; vouchers of the two pupae are in the collection of the authors. Moreover, some pupal exuviae $(n=15)$ from two BIQURA sites where the larvae was not found were examined (Table 2). Unfortunately, we were not able to make any extraction of the pupal exuviae before we prepared them in Euparal. All the vouchers of these exuviae are in the author's collection.

Additional material from Barbadocladius was present in benthic and drift samples from three different basins in Peru from our previous studies, two sites in the Cañete river (Acosta \& Prat 2010), two sites in the Mosna river and one site in the Colca river (Villamarín 2012, Ph.D. thesis). The samples were taken in 2005 and 2007 (Table 2). In the first case, benthic samples were taken with a $D$ net, and in the second case with a Surber sample (following the same methodology of the BIQURA project described earlier). In both cases, samples were fixed in the field with formaldehyde and examined in the laboratory under a stereo microscope. Slides of 14 larvae and 5 pupal exuviae from these sites were prepared following the same methodology described above. It was not possible to extract the DNA of this material.

\section{DNA extraction, PCR amplification and sequencing}

Samples for DNA molecular analysis consisted of 31 larvae and 1 pupa (Table 3). Total genomic DNA was extracted from samples preserved in $96 \%$ ethanol using the Qlamp ${ }^{\circledR}$ DNA Mini Kit (QIAGEN) or SPEEDTOOLS ${ }^{\circledR}$ Tissue DNA Extraction Kit (BIOTOOLS) following the manufacturer's protocol. A list of individuals and their corresponding localities can be found in Table 3. In addition to the Barbadocladius larvae, we used one larva of Limnophyes sp. from COT-7 (no 339) as an outgroup. The two sequences of Barbadocladius existing in GenBank, corresponding to the individuals sequenced by Cranston \& Krosch (2011), were also included in the analysis.
A total of $670 \mathrm{bp}$ of the cytochrome oxidase I gene (cox1) was amplified from each individual using C1-J-1718/C1-N-2191 (mt6/Nancy) primers. As the two Barbadocladius sequences available from GenBank (Cranston \& Krosch 2011) used the C1J-2183/C1-N-2776 (Jerry/Maggie) primers, we also amplified this gene fragment from 20 individual representatives of each clade to include in the analysis the two existing sequences. Primers and conditions used are listed in Table 4. PCR reactions were carried out in a final volume of $25 \mu \mathrm{L}$, using either Taq polymerase (Promega) or Biotools Pfu DNA Polymerase (Biotools). PCR products were cycle-sequenced in both directions using the same PCR primers and the BigDye Terminator version 3.1 Cycle Sequencing Kit (Applied Biosystems) and analysed in an $A B I 3700$ automated sequencer at the CCiTUB (Centres Científics i Tecnològics de la Universitat de Barcelona). Raw sequences were edited and assembled with GENEIOUS v. 4.6.5 (Drummond et al 2009). The new sequences used in this study have been deposited in GenBank with accession numbers KF386113-KF386145 (see Table 3).

\section{Alignment and phylogenetic analysis}

Alignment of the cox1 gene fragments was trivial due to the absence of length polymorphisms. Sequences were translated into amino acids, and no indels or stop codons were found.

Maximum Likelihood (ML) analyses were conducted using the online version of RAxML (Stamatakis et al 2008). One thousand iterations of the random addition of taxa were performed applying the parameters of Gamma model of rate heterogeneity. The online version obtained bootstrap support values from 100 pseudoreplicates. The uncorrected genetic distances between the taxa were assessed using MEGA v.5.o (Tamura et al 2011).

\section{Results}

\section{Distribution of the genus Barbadocladius in high altitude} Andean tropical streams

From the samples taken in the basins shown in Fig 1, we have collected data on the taxa composition of Chironomidae from 193 sites in the study area, with more than 6,000 larvae examined (more than 4,000 have been prepared for molecular analysis) and more than 2,000 pupal exuviae. As shown in Fig 1 and Tables 1 and 2, we have found larvae, pupae or pupal exuviae of Barbadocladius in only 13 sites in five different basins, all of them exclusively in Peru and mostly on the Pacific side, except for one sample collected on the Atlantic side (Mosna river). Barbadocladius densities were always low ( $<13$ ind $\mathrm{m}^{-2}$ ), and a total of 46 larvae, 3 pupae and 15 pupal exuviae were collected. The pupal exuviae from the BIQURA project were found only in drift samples from the Santa River 
Table 3 List of specimens included in the molecular analysis, with their identification code in Fig 2, locality and GenBank accession numbers.

\begin{tabular}{|c|c|c|c|c|c|}
\hline Code & Genus & Locality & Mt6/Nancy & Jerry/Maggie & GenBank accession no. \\
\hline 40Def & Barbadocladius sp2 & COTO5 & $x$ & $x$ & KF386118 \\
\hline $45 a$ & Barbadocladius sp2 & COTO5 & & $x$ & KF386119 \\
\hline 176 & Barbadocladius sp1 & COTo1 & $x$ & & KF386139 \\
\hline 183 & Barbadocladius sp1 & COTo1 & $x$ & & KF386142 \\
\hline 182 & Barbadocladius sp1 & COTO1 & $x$ & $x$ & KF386117 \\
\hline 177 & Barbadocladius sp1 & COTO1 & $x$ & $x$ & KF386114 \\
\hline 340 & Barbadocladius sp1 & COTO2 & $x$ & $x$ & KF386132 \\
\hline 283 & Barbadocladius sp1 & СОТоз & $x$ & $x$ & KF386125 \\
\hline 344 & Barbadocladius sp1 & сOTо2 & $x$ & $x$ & KF386131 \\
\hline 348 & Barbadocladius sp1 & COTO2 & $x$ & $x$ & KF386127 \\
\hline 341 & Barbadocladius sp1 & СOTO2 & $x$ & $x$ & KF386115 \\
\hline 446 & Barbadocladius sp1 & СOTO2 & $x$ & $x$ & KF386129 \\
\hline 342 & Barbadocladius sp1 & СOTO2 & $x$ & $x$ & KF386128 \\
\hline 447 & Barbadocladius sp1 & COTO2 & $x$ & $x$ & KF386123 \\
\hline 347 & Barbadocladius sp1 & COTO2 & $x$ & $x$ & KF386124 \\
\hline 346 & Barbadocladius sp1 & COTO2 & $x$ & $x$ & KF386116 \\
\hline 349 & Barbadocladius sp1 & COTO2 & $x$ & & KF386135 \\
\hline 111 & Barbadocladius sp1 & COTO4 & $x$ & & KF386134 \\
\hline 633 & Barbadocladius sp1 & COTO2 & $x$ & & KF386145 \\
\hline 345 & Barbadocladius sp1 & COTO2 & $x$ & & KF386136 \\
\hline 282 & Barbadocladius sp1 & соТоз & $\mathrm{x}$ & $x$ & KF386130 \\
\hline $136 a$ & Barbadocladius sp1 & сOTо4 & $x$ & $x$ & KF386122 \\
\hline $186 a$ & Barbadocladius sp1 & COTO1 & $x$ & $x$ & KF386120 \\
\hline 185 & Barbadocladius sp1 & COTo1 & $x$ & $x$ & KF386121 \\
\hline 343 & Barbadocladius sp1 & COTO2 & $x$ & $x$ & KF386126 \\
\hline 109 & Barbadocladius sp1 & COTO4 & $x$ & & KF386133 \\
\hline 281 & Barbadocladius sp1 & СОТоз & $x$ & & KF386143 \\
\hline 313 & Barbadocladius sp1 & COTo7 & $x$ & & KF386144 \\
\hline 110 & Barbadocladius sp1 & COTO4 & $x$ & & KF386137 \\
\hline 112 & Barbadocladius sp1 & СOTO4 & $x$ & & KF386138 \\
\hline 113 & Barbadocladius sp1 & СOTO4 & $x$ & & KF386141 \\
\hline 284 & Barbadocladius sp1 & сОТоз & $x$ & & KF386140 \\
\hline HQ872983 & Barbadocladius & Chile & & $x$ & HQ872983 \\
\hline HQ872984 & Barbadocladius & Argentina & & $x$ & HQ872984 \\
\hline 339 & Limnophyes & сOTo7 & $x$ & $x$ & KF386113 \\
\hline
\end{tabular}

Basin, at two sites where larvae were not found not in the drift or in the benthos samples (Table 2). We only found larvae and pupae at the same time in one site (COTO2, both analysed for molecular analysis). Individuals were always found at very high altitude (between 3,278 and 4,670 m asl), in cold water streams in Páramo or Puna areas (with scarce or no vegetation on the river shores or in the basin), in both small- and medium-sized streams with variable flow and low mineralization (Table 2).
Table 4 List of primers used in this study.

\footnotetext{
${ }^{\text {a }}$ Primer orientation
}

\begin{tabular}{lllll}
\hline Gene fragment & Primer & Or. $^{\text {a }}$ & Sequence $\left(5^{\prime}-3^{\prime}\right)$ & Reference \\
\hline cox1 & MT6 & F & GGAGGATTTGGAAATTGATTAGTTCC & Simon et al (1994) \\
& NANCY & R & CCCGGTAAAATTAAAATATAAACTTC & Simon et al (1994) \\
& JERRY & F & CAACATTATTTGATTTTTGG & Simon et al (1994) \\
& MAGGIE & R & GGATAATCAGAATATCGTCGAGG & Hedin \& Maddison (2001) \\
\hline
\end{tabular}




\section{Morphological analysis: pupae}

Cranston \& Krosch (2011) described the two species of Barbadocladius (B. andinus and B. limay) based on morphological characteristics of pupae and pharate male adults (using two male imagoes and ten pupae of the former species, and one male and several pupae of $B$. limay). The two species differ in their size in the original description: the $B$. andinus pupa is $2-2.8 \mathrm{~mm}(n=10)$ long, and the $B$. limay is 1.5 to $1.9 \mathrm{~mm}$ long $(n=8)$. The distribution of hooklets and spines on the abdomen shows conspicuous differences between both species (compare Tables 5 and 6 ). While $B$. andinus has hooklets in conjunctives TIII, TIV and SV and $\mathrm{SVI}, B$. limay has hooklets in conjunctives TII to IV and SIV to SVI ( $T=$ Tergite; $S=$ Sternite). The abdominal spines in $B$. andinus are long and narrow, while in $B$. limay, they are short and stout. The two pupae prepared for morphological examination (from site COT O2) and most of the pupal exuviae found at the two sites on the Santa River (SA15Der and SA05Der) were very similar to $B$. andinus, except for four smaller pupal exuviae found at site SAO5 that were similar to $B$. limay.

As seen in Table 5, the pupae and pupal exuviae of Peruvian material of $B$. andinus pupal types are at the lower range of size given in the original description. The thoracic horn $(T H)$ is difficult to observe and measure; in the few individuals where we have observed it, its length is close to $60 \mu \mathrm{m}$, and it is oval like in Fig $3 c$ in Cranston \& Krosch (2011). The number of hooklets and spines in tergites and sternites was very similar to the numbers given in the original description, except that the SV hooklets were never present in our examined material. We found no clear relationship between exuviae size and the number of hooklets or spines in the tergites and sternites. The length of the anal setae may be smaller than the original data of Cranston \& Krosch (2011), especially in the pupal exuviae taken from the Santa River. On the basis of these measurements, no clear differences were found between the pupal characteristics of our specimens and those of Cranston and Krosch (loc cit.).

The four pupal exuviae of $B$. limay that we found in Peru at 3,364 $\mathrm{m}$ a.s.l. are very similar to those described for this species in Cranston \& Krosch (2011) in terms of size and tergite and sternite ornamentation (Table 6). The most striking difference is that our specimens never had a hook row in sternite IV.

\section{Morphometric analysis of larvae}

According to Cranston \& Krosch (2011), only the larvae of $B$. andinus are known with certainty (because they found three larval exuviae attached to mature pupae). More larvae were found in Chile and Argentina by these authors, but they failed to find differences in the size of the larvae they collected, despite the clear differences in size between the pupa and adults of the two species they described. We have tried to find differences in the size of our larvae compared to the morphological characteristics provided by Cranston \& Krosch (loc. cit; Table 7).

We could not measure the entire size of the larvae because we used the larval body for DNA extraction and because the body length varies depending on the developmental stage. We therefore used the postmentum length as a proxy for larval size to compare our data with those of Cranston \& Krosch (2011). We also measured the head length, but the size
Table 5 Morphometric characteristics of pupae and pupal exuviae of Barbadocladius andinus (Cranston \& Krosch 2011).

The original data from Cranston \& Krosch (2011) are provided for comparison. The number $(n)$ of hooklets or spines in Tergites (T) and Sternites (S) is indicated. Measurements are in millimeters or micrometers.

$T H$ thoracic corn.

\begin{tabular}{lllll}
\hline & $\begin{array}{l}n=10 \\
\text { Cranston }\end{array}$ & $\begin{array}{l}n=2 \\
\text { COT02 } \\
\text { Range }\end{array}$ & $\begin{array}{l}n=11 \\
\text { SA15Der } \\
\text { Range }\end{array}$ & $\begin{array}{l}n=9 \\
\text { SA05Der } \\
\text { Range }\end{array}$ \\
\hline Total length $(\mathrm{mm})$ & $2-2.8$ & & $2.09-2.44$ & $1.99-2.37$ \\
TH length $(\mu \mathrm{m})$ & & ca 60 & ca 60 \\
TIII hooklets $(n)$ & $7-17$ & $9-13$ & $8-12$ & $5-11$ \\
TIII spines $(n)$ & $22-30$ & $25-37$ & $17-42$ & $15-24$ \\
TIV hooklets $(n)$ & $8-16$ & $12-13$ & $5-13$ & $7-11$ \\
TIV spines $(n)$ & $19-36$ & $27-37$ & $27-52$ & $21-36$ \\
SV hooklets & $0-6$ & & & $24-39$ \\
TV spines $(n)$ & $23-35$ & $47-52$ & $26-51$ & $24-40$ \\
TVI spines $(n)$ & $19-38$ & $35-42$ & $26-45$ & $4-11$ \\
SVI hooklets $(n)$ & $6-16$ & 5 & $3-7$ & $18-33$ \\
TVII spines $(n)$ & $17-29$ & $39-42$ & $21-45$ & $9-15$ \\
SVII spines $(n)$ & $10-15$ & $17-18$ & $9-18$ & $9-20$ \\
TVIII spines $(n)$ & $10-18$ & 20 & $10-18$ & $105-146$ \\
Anal lobe length $(\mu \mathrm{m})$ & & $130-154$ & $95-147$ & $43-96$ \\
Anal setae length $(\mu \mathrm{m})$ & $70-98$ & $83-97$ & $50-98$ & \\
\hline
\end{tabular}


Table 6 Morphometric characteristics of the pupal exuviae of Barbadocladius limay (Cranston \& Krosch 2011).

\begin{tabular}{lll}
\hline & $\begin{array}{l}\text { Cranston } \\
n=8 \\
\text { Range }\end{array}$ & $\begin{array}{l}\text { SA15 Der } \\
n=4 \\
\text { Range }\end{array}$ \\
\hline Total length $(\mathrm{mm})$ & $1.5-1.9$ & $1.75-1.93$ \\
Abdomen length $(\mathrm{mm})$ & & $1.12-1.2$ \\
TII hooklets $(n)$ & $18-20$ & $16-23$ \\
TIII hooklets $(n)$ & $17-22$ & $20-23$ \\
TIII spines $(n)$ & $19-28$ & $16-36$ \\
TIV hooklets $(n)$ & $15-21$ & $12-22$ \\
TIV spines $(n)$ & $20-32$ & $30-36$ \\
SIV hooklets $(n)$ & $0-2$ & 0 \\
TV Spines $(n)$ & $23-41$ & $30-40$ \\
SV hooklets $(n)$ & $10-20$ & $17-24$ \\
TVI spines $(n)$ & $20-39$ & $25-39$ \\
SVI hooklets $(n)$ & $18-23$ & $13-23$ \\
TVII spines $(n)$ & $21-33$ & $29-41$ \\
SVIII spines $(n)$ & $3-4$ & $10-12$ \\
TVIII spines $(n)$ & $14-18$ & $10-15$ \\
Anal lobe length $(\mu \mathrm{m})$ & & $72-111$ \\
Anal setae length $(\mu \mathrm{m})$ & & $15-24$ \\
1 & & $30-32$ \\
2 & & 42 \\
3 & & \\
\hline & & \\
\hline
\end{tabular}

As in the precedent table, we provide the original data from Cranston \& Krosch (2011) to compare with our measurements.

of the head on the slides may be heavily modified due to cover slip pressure, while the postmentum length is less variable. We measured 42 larvae, and the range of postmentum lengths was greater than the measures provided by Cranston \& Krosch (2011) (99-131 $\mu \mathrm{m}$ compared to 102-110 $\mu \mathrm{m}$; Table 7). The same is true for other measures (mentum and mandible length and the length of each antennal segment). The AR, which was close to 1.52 in. Cranston \& Krosch (2011), varied from 0.95 to 1.65 in our larvae. There was no statistical relationship between any size measure and the AR using all available data. Note that the two individuals found in COTO5 (which, according to molecular data, are different) were larger, but the values for the length of the antennal segments or the AR were in the same range as the others.

\section{Molecular data}

Molecular analysis was possible at 6 of the 14 sites were Barbadocladius was found in Peru, all concentrated in only the Cotahuasi basin in southern Peru (Fig 1, Tables 1-3). Because the pupal skins collected from some basins (Santa, Mosna, Colca and Cañete) were prepared in Euparal, or the larvae were from vouchers from previous studies (Cañete and Mosna rivers), we could not extract DNA from these samples. After DNA extraction, some individuals gave no positive results for molecular analysis, which left a total of 31 larvae and 1 pupa with good DNA extraction and amplification.

The final dataset used for the phylogenetic analysis included 32 sequences of Barbadocladius from the Cotahuasi basin, the two Barbadocladius sequences from Gene Bank (HQ872983 from Chile and HQ872084 from Argentina) by Cranston \& Krosch (2011) and one Limnophyes sp. larvae to root the tree, yielding 35 terminals and 1,280 aligned characters (see Table 3 for dataset information). The tree obtained by the ML analysis is shown in Fig 2 .

Table 7 Morphometric characteristics of the Barbadocladius larvae found in streams of Peru.

\begin{tabular}{|c|c|c|c|c|c|c|c|c|c|c|}
\hline & $\begin{array}{l}n=3 \\
\text { Cranston }\end{array}$ & $\begin{array}{l}n=6 \\
\text { COTo1 }\end{array}$ & $\begin{array}{l}n=10 \\
\text { COTO2 }\end{array}$ & $\begin{array}{l}n=4 \\
\text { COTO3 }\end{array}$ & $\begin{array}{l}n=5 \\
\text { COTO4 }\end{array}$ & $\begin{array}{l}n=2 \\
\text { COTO5 }\end{array}$ & $\begin{array}{l}n=1 \\
\text { COTo7 }\end{array}$ & $\begin{array}{l}N=3 \\
\text { CAO1 }\end{array}$ & $\begin{array}{l}n=10 \\
\text { CAO6 }\end{array}$ & $\begin{array}{l}n=1 \\
\mathrm{MOO} 3\end{array}$ \\
\hline Head length $(\mu \mathrm{m})$ & 295 & $296-330$ & $325-392$ & $266-326$ & $304-322$ & $363-380$ & 363 & $286-299$ & 307-339 & 283 \\
\hline Postmentum length $(\mu \mathrm{m})$ & $102-110$ & $103-119$ & $108-122$ & $101-114$ & $109-116$ & 130-131 & 126 & $116-119$ & $105-122$ & 99 \\
\hline Mandible length $(\mu \mathrm{m})$ & $76-85$ & $76-87$ & $86-96.6$ & $69.4-80.2$ & $76.7-84.9$ & $81-94$ & 84 & $78-83$ & $82-97$ & 77.86 \\
\hline Mentum width $(\mu \mathrm{m})$ & $53-60$ & $58-65.6$ & $64.3-78.3$ & $58.7-68.8$ & $54.2-69.9$ & $67.7-76.5$ & 81 & $75-79$ & $62-78$ & 68.23 \\
\hline $\begin{array}{l}\text { Seta submentum length } \\
\qquad(\mu \mathrm{m})\end{array}$ & $31-31$ & $23-32.4$ & $26.3-40.6$ & $30.8-35.1$ & $26.7-35.8$ & $34.5-46.9$ & 23.89 & $29-31$ & $29.6-37$ & 25.92 \\
\hline AS1 $(\mu \mathrm{m})$ & $32-33$ & $27-31$ & $27.9-32.8$ & $26.5-32.0$ & $26.9-31.4$ & $33.2-35.0$ & 34.19 & $30.4-33.4$ & $27.3-34.1$ & 25.17 \\
\hline AS2 $(\mu \mathrm{m})$ & $10-11$ & $7.30-9.94$ & $8.5-10.3$ & $8.1-10$ & $8.7-11.8$ & $10.1-11$ & 9.71 & $8.5-10.1$ & $6.8-10.3$ & 10.39 \\
\hline AS3 $(\mu \mathrm{m})$ & 5 & $5-7$ & $5.1-7.7$ & $6.2-7.4$ & $6.3-8.7$ & $7.5-7.7$ & 7.62 & $7.6-8.6$ & $6.6-9.5$ & 8.93 \\
\hline $\mathrm{AS} 4(\mu \mathrm{m})$ & 3 & $2.0-3.3$ & $2.7-3.8$ & $2.7-3.4$ & $2.1-4.0$ & $2.4-2.8$ & 3.43 & $2.6-4.1$ & $2.1-4.1$ & 3.50 \\
\hline $\mathrm{AS}_{5}(\mu \mathrm{m})$ & 3 & $1.0-2.5$ & $2.4-3.9$ & $2.3-2.9$ & $1.5-3.3$ & $2.4-3.2$ & 2.91 & $2.5-3.7$ & $2.2-3.9$ & 3.60 \\
\hline$A R(\mu m)$ & $1.5-1.52$ & $1.36-1.65$ & $1.22-1.58$ & $1.24-1.31$ & $1.2-1.48$ & $1.34-1.55$ & 1.44 & $1.26-1.39$ & $1.16-1.42$ & 0.95 \\
\hline
\end{tabular}

Sampling site codes in Table 2. The values of Cranston and Krosch (2011) are given for comparison. Only COT samples were available for molecular analysis.

$A S$ antennal segment (length), $A R$ antennal ratio. 
Fig $2 \mathrm{ML}$ tree of the Barbadocladius samples using partial cox1 gene sequences. Numbers in nodes correspond to bootstrap support values. The tree was rooted using a Limnophyes $\mathrm{sp}$, from the COTO7 site. Numbers on terminals correspond to the code of the specimens listed in Table 3. The sequences deposited in Gene Bank corresponding to the paper of Cranston and Krosch (2011) were included.

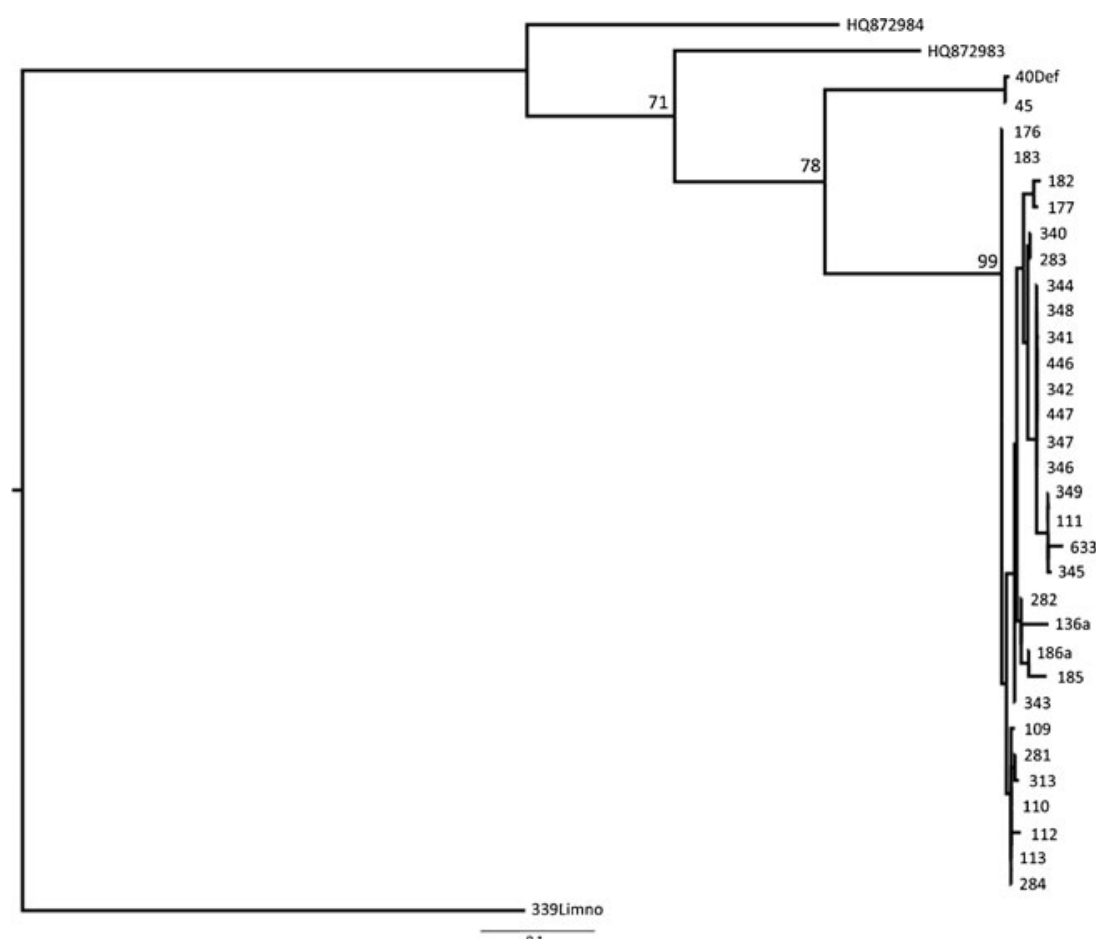

Most of the samples analysed were grouped in the same clade with high bootstrap support (99) and low internal uncorrected genetic distance $(1.03 \%)$, suggesting that the species is widely distributed throughout the basin sampled (sites COT01; COTO2, COTO3; COTO4; COTO7). The two larvae from COTO5 clustered in a separate clade with moderate support (78) and with a high uncorrected genetic distance (10.56\%) between both clades, suggesting that they constitute different evolutionary lines. As indicated previously, the two larval individuals of COTO5 were slightly larger than the others (Table 7).

The two Barbadocladius sequences from Gene Bank included in the analysis are located in a basal position. The individual HQ872983, from Chile, constitutes the sister evolutionary line of the two Peruvian representatives; and the sequence HQ872984, from Argentina, is located in the basal position on the tree. The average uncorrected genetic distance between these four clades ranges from $10.56 \%$ to $14.44 \%$ (see Table 8). Because of the geographical separation involved, this clear genetic differentiation between these four evolutionary lines indicates the existence of separate populations of the same species forming a cline from south to north, or even the presence of four putative new genetically distinct species. Unfortunately, in the absence of mature pupae or adults, we cannot discriminate between these two hypotheses.

As the two sequences deposited in Gene Bank are identified as $B$. andinus, and our pupa or pupal exuviae show similar morphological characteristics to the species description in Cranston \& Krosch (2011), at this moment it is not possible to identify the four molecular evolutionary lines using morphological characteristics.

\section{Discussion}

Barbadocladius was first reported by Cranston \& Krosch in 2011 while examining the evolution of Gondwanan Orthocladiinae. In addition to the material originally collected by Roback \& Coffmann (1983) in Bolivia (as larval taxon Genus 9 and pupal taxon Genus 4), Cranston collected more material in the Patagonian Andes. As a result, he characterized
Table 8 Mean uncorrected $p$ distances of cox 1 between (lower left) and within clusters (upper right).

\begin{tabular}{lllll}
\hline & HQ872983 & HQ872984 & Barbadocladius sp1 & Barbadocladius sp2 \\
\hline HQ872983 & & & 0.010328 & 0.001698 \\
HQ872984 & 0.134892 & & & \\
Barbadocladius sp. 1 & 0.138984 & 0.144433 & & \\
Barbadocladius sp. 2 & 0.115179 & 0.129496 & 0.105689 & 0.158823 \\
Limnophyes sp. & 0.139286 & 0.133094 & 0.157212 & \\
\hline
\end{tabular}


Barbadocladius as a trans-Andean genus distributed between $39^{\circ}$ and $41^{\circ} \mathrm{S}$ and from 260 to $1,185 \mathrm{~m}$ asl (Cranston \& Krosch 2011). In this paper, we extend the distribution further north (to $9^{\circ} \mathrm{S}$, table 2). However, the distribution is restricted in this area to very high altitude rivers and streams (above 3,278 m). The reason for these altitudinal differences in Barbadocladius distribution along the latitudinal gradient in the Andes is likely because cold stenothermic conditions in lower latitudes (Peru, Ecuador) occur at higher altitudes compared to more southerly latitudes (Patagonian Andes) where the same conditions occur at lower altitudes (Illies 1969, Jacobsen et al 1997). This means that a species' altitudinal range is highly dependent upon geographical latitude. The inverse relationship between altitude and latitude with temperature has been described for the Andes in several papers (Jacobsen et al 1997, Jacobsen 2003, Jacobsen \& Marín 2007). All of the river sites where the larvae, pupae or pupal exuvia were found are located in the Páramo or Puna, an area of cold waters without specific riparian vegetation and with only scattered shrubs in the catchment (García \& Beck 2006, Mena \& Hofstede 2006).

From our extensive sampling of 17 basins in Páramo and Puna areas ranging from $5^{\circ} \mathrm{N}$ to $16^{\circ} \mathrm{S}$, we conclude that the distribution of Barbadocladius does not extend further north than $9^{\circ} \mathrm{S}$ in the Peruvian Andes, as it has not been found in the highlands of Ecuador and Colombia. In this context, it is interesting to note that the Huancabamba Depression is situated at $6^{\circ} \mathrm{S}$ latitude (Fig 1), and constitutes a major structural and physiographic break in the Andes where continuity is partially interrupted by the confluence of the ChamanaMarañón rivers, separating the Cordillera Central from the Cordillera Oriental. The Huancabamba Depression is the lowest pass (2,145 $\mathrm{m}$ asl) between Colombia and southern Chile (Duellman \& Pramuk 1999). The present elevations and drainage patterns in the Huancabamba Depression most likely were established in the Pleistocene (Gansser 1973, Harrington 1956). During this period, climatic fluctuations included cooler, drier conditions during glacial phases and warmer and higher moisture conditions during interglacial phases. These climatic fluctuations, together with the complex topography, presumably resulted in isolation of highland areas that favored high levels of endemism (Henning et al 2011, Rivera et al 2011). Furthermore, these conditions provided geographical barriers to dispersion for many taxa, such that the Huancabamba Depression corresponds to the northern or southern limit of modern distribution of many species including frogs (Duellman \& Pramuk 1999), mantids (Rivera et al 2011) and plants (Cosacov et al 2009, Weigend et al 2010). This could also be the case for Barbadocladius in our study.

The pupae of the two species of Barbadocladius are very different in size; $B$. limay is no longer than $2 \mathrm{~mm}$ in length, while $B$. andinus always is larger than $2 \mathrm{~mm}$. The Peruvian material confirms the differences in size of the pupal exuviae. Our study of the armament characteristics of the tergites and sternites showed no clear differences between the individuals of each species described by Cranston \& Krosch (2011) and our material. According to the pupal morphology, there seem to be only two species of the genus Barbadocladius in the Andes. The morphology of the pupa found at the COTO2 site was very similar to $B$. andinus of Chile and Argentina, but the molecular analysis indicated that it may be a different species (the same species as the larvae found at the same site, which is the species more widely distributed in the Cotahuasi basin, Fig 2). As most molecular analyses have been made with larvae, the situation is even more complicated when the morphology of the larvae is compared with the molecular results because no clear differences exist between larvae of the different species obtained from the clade. The morphometric characteristics of the larvae in the paper by Cranston \& Krosch (Table 7) are those of the three larvae of $B$. andinus that they found associated with pupae.

In their notes on larvae, Cranston \& Krosch (2011) explained that all the larvae they found do not segregate into two different size classes, despite the fact that the pupae are of very different size. In addition, Cranston \& Krosch (2011) indicated that the two molecular voucher larvae deposited in Gene Bank are unreared larvae that are even larger (potsmentum length 125-126) than the $B$. andinus larvae associated with pupae (102-110), so they suggested that the two vouchers cannot be considered representative of $B$. andinus with certainty. Although we found a larger range of sizes in our material than Cranston \& Krosch (2011), with large variability between sampling sites (Table 7), we cannot differentiate two groups of larvae by size. However, at the molecular level, we found two different clades in the Cotahuasi basin, one widely distributed (five sites, between 3,278 and 4,670 $\mathrm{m}$ asl) and the other present at only one site (COTO5) at 4,486 m asl. The larvae of the COTO5 site are the largest that we found. Finally, the phylogenetic analysis (based on larvae) shows that the molecular arrangement of the two larvae from Chile and Argentina deposited at Gene Bank is different from those of Peru and even different between them, suggesting that four populations of the same species, genetically quite differentiated, are present in the high altitude tropical Andes, which could even be considered four different species.

Krosch et al (2011), in studying the evolutionary relationships of putative Gondwanan Orthocladiinae using molecular techniques, included the genus Barbadocladius as a sister group of a large and diverse clade estimated to comprise taxa largely of Gondwanan distribution. According to Krosch et al (2011), the pupal structures of this genus resemble those of the genus Eukiefferiella (absent from South America), indicating that this taxa may be an ecological vicariant of that taxa, although is not as frequent and abundant as Eukieferiella is in European and North American streams and rivers. As indicated by Cranston \& Krosch (2011), the presence of hooklets in 
pupae seems to be a homoplasious feature, existing in other distant genera. The larva is totally different from other larvae of Orthocladiinae, with some similarities to those of the genus Synorthocladius. The morphological analysis of the Peruvian Barbadocladius does not change the assumption of Cranston \& Krosch that this is a sister clade to a large clade that comprises taxa largely of Gondwanan distribution (Krosch et al 2011). However, the molecular analysis reveals more specific taxonomic variability than what was found in Argentina and Chile, indicating the possible presence of a speciation in process from south to north along the Andes. Additionally, climatic fluctuations during the Pleistocene may also have contributed to speciation through isolation of many cold stenothermic taxa (such as Barbadocladius) in high altitude refuges (Jacobsen et al 1997, Rivera et al 2011). We hypothesize that several cryptic species are present along the latitudinal gradient from $41^{\circ}$ to $9^{\circ} \mathrm{S}$. In the future, new samples from the original site in Bolivia, where the species was first caught by Roback \& Coffmann (1983), could confirm if there is a cline between the taxa we have collected in Peru and those from Patagonia collected by Cranston \& Krosch (2011).

In conclusion, we have extended the distribution of the genus Barbadocladius further north, but also restricted its distribution to south of latitude $6^{\circ}$. In its present northern distribution, it is restricted to very high altitude streams, confirming that this is a trans-Andean taxa (present in both the Pacific and Atlantic rims) with a Gondwanan distribution. Although from the morphology of larvae and pupae no more than the two species may be differentiated, the molecular analysis suggested that several cryptic species may exist in the area between 9 and $41^{\circ} \mathrm{S}$. As for the moment few materials have been studied, we cannot establish how many species are in this large area with certainty. We suspect that a clear cline effect exists. Given its distribution, the altitudinal gradient (inversely proportional to the latitude), and the high altitude where the populations are found in Peru, the Barbadocladius species complex could be considered in the high part of the Andes as a set of isolated Gondwanan species located in mountain refuges where the ecological conditions allow their survival.

Acknowledgments The authors are very indebted to our Latin American colleagues that made possible the collection of chironomid larvae in Colombia (Lucimar Gomes, Universidad de Caldas), Ecuador (Andrea Encalada and Natalia García, Universidad San Francisco de Quito) and Peru (Clorinda Vergara and Javier Huanca, Universidad Nacional Agraria de La Molina). Many other people helped in the field collections, and we thank Carolina Arroyo, Fernanda González, Karla Jiménez and Manuel Andía for their support. Núria Sánchez Millaruelo prepared most of the slides, and Pau Fortuño prepared the figures.

Electronic supplementary material The online version of this article (doi:10.1007/s13744-013-0161-1) contains supplementary material, which is available to authorized users.

\section{References}

Acosta R, Prat N (2010) Chironomidae assemblages in high altitude streams of the Andean region of Peru. Fundam Appl Limnol 177:57-79

Cosacov A, Sérsic AN, Sosa V, De-Nova JA, Nylinder S, Cocucci AA (2009) New insights into the phylogenetic relationships, character evolution, and phytogeographic patterns of Calceolaria (CALCEOLARIACEAE). Am J Bot 96:2240-2255

Cranston PS, Krosch M (2011) Barbadocladius Cranston \& Krosch, a new genus of Orthocladiinae (Diptera: Chironomidae) from South America. Neotrop Entomol 40:560-567

Drummond AJ, Ashton B, Cheung M, Heled J, Kearse M, Moir R, StonesHavas S, Thierer T, Wilson A (2009) Geneious v.4.6.5. created by Biomatters

Duellman WE, Pramuk JB (1999) Frogs of the Genus Eleutherodactylus (Anura: Leptodactylidae) in the Andes of Northern Peru. Scientific Papers. Natural History Museum The University of Kansas 13: 1-78

Epler J (2001) Identification manual for the Iñarval Chironomidae (Diptera) of North and South Carolina. A guide to the taxonomy of the midges of southeastern United States, including Florida. North Carolina Department of Environment and Natural Resources, Raleigh, NC and St. Johns River Water Management District, Plalatka, FL., Special Publication SJ2011-SP13, pp 526

Gansser A (1973) Facts and theories on the Andes. J Geol Soc (London UK) 129:93-131

García E, Beck S (2006) Puna, p. 51-76. In: Moraes M, Øllgaard B, Kvist $\mathrm{LP}$, Borchsenius F, Balslev $\mathrm{H}$ (eds) Botánica Económica de los Andes Centrales. Universidad Mayor de San Andrés, La Paz

Harrington HJ (1956) Main morphostructural regions of South America. In: Jenks WF (ed) Handbook of South American geology. Memoir, Geological Society of America, Boulder, p. xii-xviii

Hedin MC, Maddison WP (2001) A combined molecular approach to phylogeny of the jumping spider subfamily Dendryphantinae (Araneae: Salticidae). Mol Phylogenet Evol 18:386-403

Henning T, Rodríguez EF, Weigend M (2011) A revision of the Nasa ranunculifolia group (Nasa ser. Grandiflorae pro parte, Loasaceae). Bot J Linn Soc 167:47-93

Illies J (1969) Biogeography and ecology of neotropical freshwater insects, especially those from running waters. In: Fittkau EJ, Illies J, Kling $H$, Schwabe GH, Sioli $H$ (eds) Biogeography and ecology in South America, Ilth edn. Springer, Netherlands, pp 685-708

Jacobsen D (2003) Altitudinal changes in diversity of macroinvertebrates from small streams in the Ecuadorian Andes. Arch Hydrobiol 158: 145-167

Jacobsen D, Marín R (2007) Bolivian Altiplano streams with low richness of macroinvertebrates and large diel fluctuations in temperature and dissolved oxygen. Aquat Ecol 42:643-656

Jacobsen D, Schultz R, Encalada AC (1997) Structure and diversity of stream invertebrate assemblages: the influence of temperature with altitude and latitude. Freshwater Biol 38:247-261

Krosch MN, Baker AM, Cranston PS (2011) Systematics and biogeography of the Gondwanan Orthocladiinae (Diptera: Chironomidae). Mol Phylogenet Evol 59:458-468

Mena P, Hofstede R (2006) Los páramos ecuatorianos, p 91-109. In: Moraes M, Øllgaard B, Kvist L, Borchsenius F, Balslev H (eds) Botánica Económica de los Andes Centrales. Universidad Mayor de San Andrés, La Paz

Nuñez M, Prat N (2010) Efectos de la sequía y las crecidas en los índices biológicos en el río Llobregat. Tecnología del Agua 30:46-55

Prat N, Acosta R, Villamarín C, Rieradevall M (2012) Guía para el reconocimiento de las larvas de Chironomidae (Diptera) de los ríos Altoandinos de Ecuador y Perú. Clave para la determinación de los principales morfotipos larvarios. Grupo de Investigación F.E.M. (Freshwater Ecology and Management), Departament d'Ecologia, 
Universitat de Barcelona. http://www.ub.edu/riosandes/index.php/ guiachiros.html Accessed 13 May 2013.

Rivera J, Yagui H, Ehrmann R (2011) Mantids in the Mist-taxonomy of the Andean genus Pseudopogonogaster Beier, 1942, a cloud forest specialist, with notes on its biogeography and ecology (Mantodea: Thespidae: Miopteryginae). Insect Syst Evol 42:313-335

Roback SS, Coffman WP (1983) Results of the Catherwood BolivianPeruvian Altiplano Expedition. Part II. Aquatic Diptera including montane Diamesinae and Orthocaldiinae (Chironomidae) from Venezuela. Proc Acad Nat Sci Philadelphia 135:9-79

Simon C, Frati F, Beckenbach A, Crespi B, Liu H, Flook P (1994) Evolution, weighting, and phylogenetic utility of mitochondrial gene-sequences and a compilation of conserved polymerase chain reaction primers. Ann Entomol Soc Am 87:651-701

Stamatakis A, Hoover P, Rougemont J (2008) A rapid bootstrap algorithm for the RAxML web-servers. Syst Biol 75:758-771
Tamura K, Peterson D, Peterson N, Stecher G, Nei M, Kumar S (2011) MEGA5: Molecular Evolutionary Genetics Analysis using maximum likelihood, evolutionary distance, and maximum parsimony methods. Mol Biol Evol 28:2731-2739

Villamarín C (2012) Estructura y composición de las comunidades de macroinvertebrados acuáticos en ríos altoandinos del Ecuador y Perú. Diseño de un sistema de medida de la calidad del agua con índices multimétricos. Ph.D. Thesis, Universitat de Barcelona, Barcelona, Spain, p 207.

Villamarín C, Rieradevall M, Paul MJ, Barbour MT, Prat N (2013) A tool to assess the ecological condition of tropical high Andean streams in Ecuador and Peru: the IMEERA index. Ecol Indic 29:79-92

Weigend M, Gottschling M, Hilgeri HH, Nürk N (2010) Five new species of Lithospermum L. (Boraginaceae tribe Lithospermeae) in Andean South America: another radiation in the Amotape-Huancabamba Zone. Taxon 59:1161-1179 